\title{
DISPENSASI KAWIN DALAM TINJAUAN UNDANG-UNDANG NOMOR 23 TAHUN 2002 JUNCTO UNDANG-UNDANG NOMOR 35 TAHUN 2014 TENTANG PERLINDUNGAN ANAK
}

\author{
oleh : \\ Achmad Bahroni ${ }^{1}$, Ariella Gitta Sari ${ }^{2}$, Satriyani Cahyo Widayati ${ }^{3}$, Hery Sulistyo ${ }^{4}$
}

\begin{abstract}
Abstraksi
Dispensasi kawin adalah sebuah kebijakan hukum yang memberikan kebolehan bagi anak-anak dibawah umur yang memenuhi kaidah dimana diatur dalam dispensasi tersebut untuk dapat melangsungkan perkawinan yang sah secara hukum di Indonesia. Dimana sebenarnya sesuai dengan peraturan UU Perkawinan Nomor 1 Tahun 1974 usia mereka masih dibawah batas kedewasaan dan tentu saja belum dapat menikah. Kasus yang sering terjadi dan melatarbelakangi dispensasi kawin ini adalah banyaknya kehamilan-kehamilan diluar nikah pada usia remaja. Dispensasi kawin diberikan dengan tujuan utama untuk memberikan kepastian hukum bagi bayi yang akan dilahirkan. Penelitian ini adalah penelitian normatif deskriptif, data akan disajikan dalam bentuk narasi-narasi dan diharapkan dapat dipahami. Hasil penelitian menunjukkan bahwa sebenarnya meskipun menjadi solusi secara hukum, namun dispensasi nikah dirasa tidak mendidik bagi generasi penerus. Dikhawatirkan secara sosial, makin marak terjadi pernikahan-pernikahan dini yang berasal dari dispensasi kawin dan menjadi keluarg yang buruk karena tidak siapnya mental dan spiritual. Peran keluarga sangat dibutuhkan dalam hal ini agar anak-anak yang tiba-tiba terpaksa menjalani kehidupan berumah tangga, tetap mendapatkan kasih sayang orang tua dan dapat tumbuh dan berkembang dengan baik hingga dewasa. Perlindungan anak yang paling efektif tetaplah perlindungan dan pemahaman cinta kasih dari orang tua dan lingkungan keluarganya. jangan sampai terjadi pembullian, olok-olok dan lain sebagainya yang akan menghancurkan harapan sang anak.
\end{abstract}

Kata Kunci : $\quad$ dispensasi kawin, perlindungan anak

\footnotetext{
Dosen Fakultas Hukum Universitas Kadiri, email : achmadbahroni@unik-kediri.ac.id

Dosen Fakultas Hukum Universitas Kadiri, email : ariellagitta@unik-kediri.ac.id

Dosen Fakultas Hukum Universitas Kadiri, email : satriyani@unik-kediri.ac.id

Dosen Fakultas Hukum Universitas Kadiri, email : hery sulistyo@unik-kediri.ac.id
} 


\section{Latar Belakang}

Pernikahan di Indonesia telah diatur oleh negara, dalam hal ini negara memberikan perhatian sekaligus memiliki tanggung jawab dalam mengontrol serta memberikan pengarahan mengenai perkawinan yang merupakan Institusi sosial dalam melindungi dan menjunjung harga diri perempuan. Oleh sebab itu, Negara dan Pemerintah membuat peraturan mengenai batas usia minimal seseorang dalam melaksanakan pernikahan. Peraturan tersebut telah dijelaskan dalam Undang-Undang Nomor 1 Tahun 1974 tentang perkawinan, yang didalamnya diterangkan mengenai batasan usia seseorang dalam melaksanakan perkawinan untuk mencapai suatu perkawinan yang baik dan ideal dengan usia yang cukup matang. Dimana batas minimal seseorang bisa melakukan perkawinan adalah 19 tahun untuk laki-laki dan 16 tahun untuk perempuan, (pasal 7 ayat 1 UU No. 1 tahun 1974). Dalam pasal ini terdapat beberapa Kaidah yang menjamin suatu pernikahan agar berjalan dengan baik sesuai dengan tujuan pernikahan itu sendiri. yakni atas dasar Ketulusan, partisipasi keluarga dan kesiapan mental serta fisik kedua calon pengantin.

Dalam membangun suatu perkawinan yang baik sangat diperlukan tanggung jawab serta pemikikiran dewasa diantara kedua belah pihak calon pengantin, oleh karena itu Kesiapan mental dan fisik merupakan hal yang paling penting dan utama dalam suatu perkawinan sehingga dapat terciptanya keluarga yang bahagia. Dalam melakukan komunikasi diharapan pasangan bisa berpikir secara dewasa mengingat bahwa kedewasaan pasangan dalam membangun rumah tangga adalah penting, kedewasaan yang dimaksud adalah mengibaratkan bahwa pasangan adalah seorang 
partner atau teman hidup, sehingga komunikasi dapat berlangsung dengan baik. Kematangan calon suami istri dimaksudkan bahwa pasangan telah mampu secara fisik maupun mental menjalankan suatu perkawinan untuk bisa mewujudkan tujuan perkawinan tersebut.

Kesiapan fisik adalah salah satu persiapan perkawinan yang matang untuk mewujudkan keluarga yang tentram dan bahagia, dengan fisik yang sehat, mampu bersikap dewasa, serta mampu memberikan biaya hidup dalam rumah tangga, maka itu tandanya suami istri telah membangun fondasi awal untuk mewujudkan rumah tangga yang bahagia ke depannya. Jika dalam suatu perkawinan tidak dipersiapkan dengan matang secara fisik maka dikhawatirkan akan terjadi suatu kegagalan dalam rumah tangga, sehingga perlu adanya pencegahan perkawinan dibawah umur. Walaupun sudah diatur dalam Undang-Undang mengenai batasan usia seseorang dalam melakukan perkawinan, namun tidak dapat dipungkiri bahwa pernikahan dibawah umur tetap ada.

Pernikahan seseorang yang belum mencukupi umur tetap bisa dilaksanakan dengan syarat apabila Wali dan Pengadilan Agama telah memberikan izin. Permohonan izin untuk menikah dibawah umur yang diajukan kepada Pengadilan Agama dinamakan Dispensasi Kawin. sesuai ketetapan Pasal 7 ayat (2) jis Pasal 63 UU No. 1 Tahun 1974, Pasal 49 huruf (a) UU Nomor 7 Tahun 1989 yang telah diubah dengan UU Nomor 3 Tahun 2006 dan perubahan kedua dengan UU Nomor 50 Tahun 2009, Dispensasi kawin secara absolut memang menjadi kompetensi Pengadilan Agama. Persoalan mengenai seseorang yang membutuhkan lembaga 
hukum ini pada dasarnya hanya persoalan umur. Dimana dalam hal ini ketika seseorang yang ingin melangsungkan pernikahan namun usianya belum mencukupi umur yang telah ditentukan oleh Undang-Undang yakni 16 untuk perempuan dan 19 untuk laki-laki maka dapat mengajukan permohonan dispensasi kawin kepada pengadilan agama untuk melakukan perkawinan.

Sebagaimana yang terjadi di pengadilan Agama Kota Kediri telah terdaftar diantaranya sebesar 39 perkara Dispensasi kawin diantara 538 perkara di tahun 2016, dan pada tahun $2017^{1}$ hingga pada bulan juli ditahun yang sama telah terdaftar sebesar 29 perkara dispensasi kawin diantara 262 perkara. Pengadilan Agama juga memiliki kewenangan yang berkaitan dengan Undang-Undang Perlindungan Anak, diantaranya adalah membuat penetapan asal usul dari seoarang anak dan adopsi anak sesuai dengan hukum islam, gugatan nafkah anak, gugatan/permohonan pengakuan anak,

dll.

\section{Rumusan Masalah}

2.1. Bagaimana dispensasi kawin tersebut ditinjau dari Undang-undang Nomor 23 Tahun 2002 sebagaimana di ubah dengan Undang-undang Nomor 35 Tahun 2014 tentang perlindungan anak ?

2.2. Faktor-faktor apa yang menjadi penyebab dari meningkatnya permohonan dispensasi kawin di pengadilan agama Kota Kediri ?

\section{Tujuan Penelitian}

Penelitian ini bertujuan untuk mencari serta mengungkapkan fakta terkait bagaimana dispensasi kawin yang memungkinkan anak-anak dibawah umur menikah 
karena suatu alas an yang dapat diterima hakim dipandang atau dikaji dari sudut pandang perlindungan anak. Diharapkan penelitian ini dapat memperkaya khasanah pengetahuan khususnya ilmu hokum yang senantiasa berkembang dari hari ke hari. Khususnya kepada pemerintah Republik Indonesia yang berkewajiban untuk melindungi masa depan anak-anak, semoga hasil penelitian ini dapat memberikan masukan berharga.

\section{Teori Perlindungan hukum}

Terkait dengan teori perlindungan hukum, ada beberapa ahli yang menjelaskan bahasan ini, antara lain yaitu Fitzgerald, Satjipto Raharjo, Phillipus M Hanjon dan Lily Rasyidi. Fitzgerald mengutip istilah teori perlindungan hukum dari Salmond bahwa hukum bertujuan mengintegrasikan dam mengkoordinasikan berbagai kepentingan dalam masyrakat karena dalam suatu lalulintas kepentingan, perlindungan terhadap kepentingan tertentu dapat dilakukan dengan cara membatasi berbagai kepentingan di lain pihak. Kepentingan hukum adalah mengurusi hak dan kepentingan manusia, sehingga hukum memiliki otoritas tertinggi untuk menentukan kepentingan manusia yang perlu diatur dan dilindungi. Perlindungan hukum harus melihat tahapan yakni perlindungan hukum lahir dari suatu ketentuan hukum dan segala peraturan hukum yang diberikan oleh masyarakat yang pada dasarnya merupkan kesepakatan masyarakat tersebut untuk mengatur hubungan perilaku antara 
anggota-anggota masyarakat dan antara perseorangan dengan pemerintah yang dianggap mewakili kepentingan masyarakat. ${ }^{5}$

Menurut Satjipto Rahardjo, Perlindungan hukum adalah memberikan pengayoman terhadap hak asasi manusia (HAM) yang dirugikan orang lain dan perlindungan itu diberikan kepada masyarakat agar dapat menikmati semua hak-hak yang diberikan oleh hukum. ${ }^{6}$ Selanjutnya menurut Phillipus M. Hadjon bahwa perlindungan hukum bagi rakyat sebagai tindakan pemerintah yang bersifat preventif dan resprensif. Perlindungan Hukum yang preventif bertujuan untuk mencegah terjadinya sengketa, yang mengarahkan tindakan pemerintah bersikap hati-hati dalam pengambilan keputusan berdasarkandiskresi dan perlindungan yang resprensif bertujuan untuk mencegah terjadinya sengketa, termasuk penanganannya di lembaga peradilan. ${ }^{7}$ Sedangkan menurut Lili Rasjidi dan I.B Wysa Putra bahwa hukum dapat didifungsikan untuk menghujudkan perlindungan yang sifatnya tidak sekedar adaptif dan fleksibel, melaikan juga predektif dan antipatif. ${ }^{8}$

Dari uraian para ahli diatas memberikan pemahaman bahwa perlindungan hukum merupakan gambaran dari bekerjanya fungsi hukum untuk mewujudkan tujuan-tujuan hukum, yakni keadilan, kemanfaatan dan kepastian hukum. Perlindungan hukum adalah suatu perlindungan yang diberikan kepada subyek hukum sesuai dengan aturan hukum, baik itu yang bersifat preventif maupun dalam

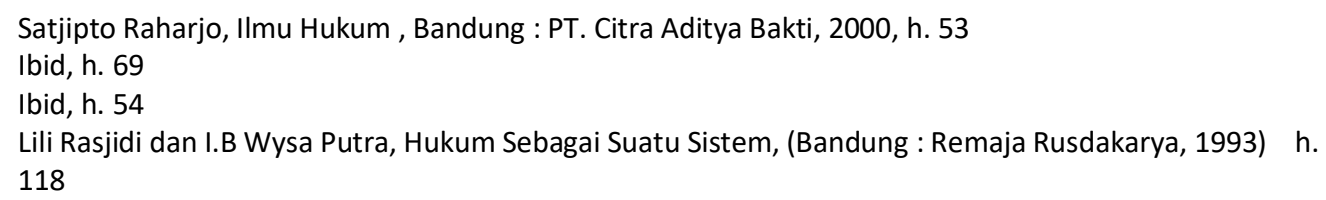


bentuk yang bersifat represif, baik yang secara tertulis maupun tidak tertulis dalam rangka menegakkan peraturan hukum.

\section{Teori Perlindungan Konsumen}

Prinsip-prinsip mengenai kedudukan konsumen dalam hubungan dengan pelaku usaha berdasarkan doktrin atau teori yang dikenal dalam perkembangan sejarah hukum perlindungan konsumen, antara lain :

a. Let the buyer beware (caveat emptor)

Doktrin let the buyer beware atau caveat emptor merupakan dasar dari lahirnya sengketa dibidang transaksi konsumen. Asas ini berasumsi bahwa pelaku usaha dan konsumen adalah dua pihak yang sangat seimbang, sehingga konsumen tidak memerlukan perlindungan. Prinsip ini mengandung kelemahan, bahwa dalam perkembangan konsumen tidak mendapat informasi yang memadai untuk menentukan Pilihan terhadap barang dan/atau jasa yang dikonsumsinya. Hal tersebut dapat disebabkan oleh keterbatasan pengetahuan konsumen atau ketidakterbukaan pelaku usaha terhadap produk yang ditawarkannya. Dengan demikian, apabila konsumen mengalami kerugian, maka pelaku usaha dapat berdalih bahwa kerugian tersebut akibat dari kelalaian konsumen sendiri.

b. The due care theory

Doktrin ini menyatakan bahwa pelaku usaha mempunyai kewajiban untuk berhatihati dalam memasarkan produk, baik barang maupun jasa. Selama pelaku usaha 
berhati-hati dengan produknya, maka ia tidak dapat dipersalahkan. Pada prinsip ini berlaku pembuktian siapa mendalilkan maka dialah yang membuktikan. Hal ini sesuai dengan jiwa pembuktian pada hukum privat di Indonesia yaitu pembuktian ada pada penggugat, sesuai dengan pasal $1865 \mathrm{BW}$ yang secara tegas menyatakan bahwa barangsiapa yang mendalilkan mempunyai suatu hak atau untuk meneguhkan haknya atau membantah hak orang lain, atau menunjuk pada suatu peristiwa, maka diwajibkan mebu ktikan adanya hak atau peristiwa tersebut. c. The privity of contract Doktrin ini menyatakan pelaku usaha mempunyai kewajiban untuk melindungi konsumen, tetapi hal itu baru dapat dilakukan jika diantara mereka telah terjalin suatu hubungan kontraktual. Pelaku usaha tidak dapat disalahkan diluar hal-hal yang dperjanjikan. Dengan demikian konsumen dapat menggugat berdasarkan wanprestasi. Hal ini sesuai dengan ketentuan dalam pasal 1340 BW yang menyatakan tentang ruang lingkup berlakunya perjanjian hanyalah antara pihak-pihak yang membuat perjanjian saja. ${ }^{9}$

Asas dan Tujuan Perlindungan Konsumen Perlindungan konsumen diselenggarakan sebagai usaha bersama berdasarkan lima asas yang relevan dalam pembangunan nasional, yakni:

\section{a. Asas Manfaat}

Adalah segala upaya dalam menyelenggarakan perlindungan konsumen harus memberikan manfaat sebesarbesarnya bagi kepentingan konsumen dan pelaku usaha secara keseluruhan.

9 Shidarta, Hukum Perlindungan Konsumen Indonesia, PT Grasindo, Jakarta, 2006, h. 61 
b. Asas Keadilan

Adalah memberikan kesempatan kepada konsumen dan pelaku usaha untuk memperoleh haknya dan melaksanakan kewajibannya secara adil.

c. Asas Keseimbangan

Adalah memberikan keseimbangan antara kepentingan konsumen, pelaku usaha, dan pemerintah dalam arti materiil maupun spiritual.

d. Asas Keamanan dan Keselamatan

Konsumen Adalah untuk memberikan jaminan atas keamanan dan keselamatan kepada konsumen dalam penggunaan, pemakaian, dan pemanfaatan barang dan atau jasa yang dikonsumsi atau digunakan.

e. Asas Kepastian Hukum

Adalah pelaku maupun konsumen mentaati hukum dan memperoleh keadilan dalam penyelenggaraan perlindungan konsumen serta negara menjamin kepastian hukum. ${ }^{10}$

\section{Pengertian Anak Dalam Perundangan}

melihat dari beberapa peraturan perundangan, ternyata terdapat perbedaan mengenai batas usia seseorang bisa dikatakan sebagai anak. Dibawah ini adalah batasan usia dimana seseorang dapat dikatakan sebagai anak :

1. KUHperdata Tahun 1847 pasal 330 ayat (1) "Seorang belum dapat dikatakan dewasa jika orang tersebut umurnya belum genap 21 tahun, kecuali seseorang tersebut telah menikah sebelum umur 21 tahun“.

10 Elsi, Advendi, Hukum Dalam Ekonomi, PT Grasindo:Jakarta,2007,h.159 
2. KUHP Pasal 45 “ anak yang belum dewasa apabila seseorang tersebut belum berumur 16 tahun

3. Undang-Undang Nomor 4 Tahun 1979 Tentang Kesejahteraan Anak Pasal 1 ayat 2 "Anak adalah seseorang yang belum mencapai umur 21 (dua puluh satu) tahun dan belum pernah kawin.”

4. Konvensi Hak-hak Anak yang dikeluarkan pada tahun 1989 "Anak adalah setiap manusia yang berusia di bawah 18 tahun, kecuali berdasarkan yang berlaku bagi anak tersebut ditentukan bahwa usia dewasa dicapai lebih awal"

5. Undang-Undang Nomor 3 Tahun 1997 Tentang Pengadilan Anak Pasal 1 ayat 1 “Anak adalah orang yang dalam perkara Anak Nakal telah mencapai umur 8 (delapan) tahun tetapi belum mencapai umur 18 (delapan belas) tahun dan belum pernah kawin“

6. Undang-Undang Nomor 25 tahun 1997 tentang Ketenagakerjaan Pasal 1 ayat 20 "anak adalah orang laki-laki atau wanita yang berumur kurang dari 15 tahun"

7. Undang-Undang Nomor 39 tahun 1999 tentang HAM Pasal 1 ayat 5 "Anak adalah setiap manusia yang berusia di bawah 18 (delapan belas) tahun dan belum menikah, terrnasuk anak yang masih dalam kandungan apabila hal tersebut adalah demi kepentingannya."

8. Undang-Undang RI Nomor 23 Tahun 2002 tentang Perlindungan Anak Pasal 1 ayat 1 "Anak adalah seseorang yang belum berusia 18 (delapan belas) tahun, termasuk anak yang masih dalam kandungan” 
9. Undang-Undang RI Nomor 21 tahun 2007 tentang Pemberantasan Tindak Pidana Perdagangan Orang Pasal 1 ayat 5 “Anak adalah seseorang yang belum berusia 18 (delapan belas) tahun, termasuk anak yang masih dalam kandungan."

10. Undang-Undang Nomor 44 tahun 2008 tentang Pornografi Pasal 1 ayat 4 "Anak adalah seseorang yang belum berusia 18 (delapan belas) tahun“"

\section{Batasan Usia Menikah Dalam Islam}

Di dalam Islam tidak ada pembatasan usia seseorang untuk melakukan perkawinan, hal ini sesuai dengan pasal 7 ayat (1) Undang-Undang perkawinan. Menurut syari'at islam dalam menilai kedewasaan seseorang adalah ketika seseorang tersebut sudah baligh. Dan menurut ulama ahli fikih seseorang dapat dikatakan dewasa apabila telah keluar mani untuk laki-laki dan telah datang haid untuk perempuan. ${ }^{11}$ Sebagaimama yang ada pada kitab-kitab fikih yang mana tidak menjelaskan mengenai usia minimal seseorang dalam melaksanakan sebuah perkawinan. Sebaliknya dalam kitab fikih menjelaskan bahwa seseorang perempuan dan laki-laki yang masih kanak kanak diperbolehkan melakukan perkawinan. Dimana Kebolehan ini disampaikan secara langsung maupun tidak langsung seperti yang terdapat di tiap-tiap kitab fikih yang menuturkan mengenai wewenang seorang wali mujbir untuk menikahkan anak-anak yang belum dewasa(anak-anak) ataupun masih perawan. $^{12}$

\footnotetext{
Mufidah, Isu -Isu Gender Kontemporer Dalam Hukum Keluarga, hlm. 147.

Amir Syarifuddin, Hukum Perkawinan Islam di Indonesia, Antara Fiqh Munakahat dan Undang-ndang Perkawinan, (Jakarta: Kencana, 2006), hlm. 66.
} 
Dalam Hak ijabar dikatakan bahwa hanya seorang ayah dan kakek saja yang memiliki hak untuk menikahkan tanpa harus mendapat persetujuan dari orang yang bersangkutan, tetapi lebih baik untuk meminta persetujuan kepada putrinya. ${ }^{13} \mathrm{Hal}$ tersebut dinyatakan boleh karena tidak terdapat ayat dalam Al-Qur'an yang mengatakan secara jelas mengenai batasan umur melakukan perkawinan dan dalam hadist Nabi pun tidak mengatakan secara langsung mengenai batasan umur seseorang dalam melaksanakan perkawinan. Sebagaimana yang telah tertera pada pasal 7 ayat (1) dimana mengatur mengenai batasan umur dalam melaksanakan sebuah perkawinan.

Secara jelas dalam Kitab Al-Qur'an telah diterangkan bahwa tidak terdapat batasan usia untuk dapat melakukan pernikahan, melainkan kualitas seseorang yang akan dinikahilah yang memiliki batasan sebagaimana yang diterangkan di dalam AlQu'an surat an-Nisa' ayat 6 yang artinya: "Dan ujilah anak-anak yatim itu sampai mereka cukup umur untuk menikah. Kemudian jika menurut pendapatmu mereka telah cerdas (pandai memelihara harta) maka serahkanlah kepada mereka hartanya," Ayat yang mengatakan telah cukup umur untuk menikah berarti seusai muncul kemauan untuk membina rumah tangga, dan telah memiliki kesiapan untuk menjadi seorang suami untuk menjadi pemimpin dalam rumah tangga, namun hal tersebut tidak akan berlangsung secara sempurna jika belum bisa mengatur harta kekayaannya. Para Ahli fiqih dan ahli undang-undang sesuai dengan ketetapan umum telah membuat ketentuan, dimana setelah seseorang baligh dia memiliki

13 Wahbah Zuhaili, Al-Fiqhu Asy-Syafi'i Al-Muyassar, (Beirut: Darul Fikr, 2008), hlm. 461. 
kebebasan dalam menentukan jalan hidupnya, dan diharapkan untuk bertanggung jawab sesuai dengan perbuatannya.

Meskipun di dalam Al-Qur'an tidak ada batasan umur seseorang untuk melakukuan pernikahan, tetapi dalam UU perkawinan telah diatur bahwa batas umur seseorang dalam melakukan pernikahan merupakan salah satu syarat, hal ini sesuai dengan pasal 7 ayat (1). Walaupun telah ada ketetapan mengenai batas usia dalam pernikahan namun tidak dapat dipungkiri jika pernikahan diusia dini tetap terjadi, dimana terdapat pasal 7 ayat (2) yang memberikan pengecualian mengenai batasan umur tersebut dengan cara mengajukan dispensasi kawin ke pengadilan yang ditunjuk oleh orang tua kedua belah calon pengantin. Akan tetapi syarat untuk melakukan dispensasi ini tidak disebutkan oleh undang-undang, sebagaimana hubungan terlarang diluar nikah, hal ini tersirat dalam surat an-Nur ayat 3 yang artinya: "Lelaki pezina tidak menikah, kecuali dengan perempuan pezina atau perempuan musyrik. Dan perempuan pezina tidak dinikahi, melainkan oleh lelaki pezina atau lelaki musyrik. Dan diharamkan yang demikian itu kepada semua mukmin."

Karena adanya pasal 7 ayat (2) membuat masyarakat bisa melakukan pernikahan dibawah umur dengan mengajukan dispensasi kawin, hal ini dilakukan oleh masyarakat biasanya dengan alasan untuk menghindari terjadinya zina dan hubungan terlarang diluar nikah bahkan dengan alasan telah hamil sebelum melakukan pernikahan. Terlepas dari alasan tersebut, masyarakat harus tau mengenai dampak yang ditimbulkan kedepannya. Pasangan yang menikah dibawah umur belum memiliki kesiapan mental dan fisik yang matang. 


\section{Pembahasan}

\subsection{Pemberian Dispensasi Kawin Berdasarkan UU Perlindungan Anak}

Undang-undang Nomor 23 tahun 2002 tentang Perlindungan anak dibuat berdasarkan empat prinsip (pasal 2 UU Perlindungan Anak ), yaitu :

a. Non-diskriminasi;

b. Kepentingan terbaik bagi anak;

c. Hak untuk hidup, kelangsungan hidup, dan perkembangan, dan;

d. Penghargaan terhadap anak.

Kemudian, dikatakan dalam undang-undang mengenai beberapa hak seorang anak yang wajib terpenuhi, yakni :

1. Hak dalam memperoreh sebuah pendidikan;

Seorang anak memiliki hak untuk memperoleh pendidikan, jika seorang anak sudah menikah otomatis anak tersebut akan mengabaikan pendidikannya karena harus mengurus suami dan anaknya, padahal sebuah pendidikan itu sangat penting untuk masa depannya, oleh karena itu seorang anak berhak memperoleh pendidikan.

2. Hak dalam berpikir serta berekspresi;

Sebagaimana yang telah dijelaskan dalam UU No. 23 tahun 2002 mengenai Perlindungan Anak dijelaskan bahwa "setiap anak berhak untuk berpikir dan berekspresi sesuai dengan tingkat kecerdasan dan usianya dalam bimbingan orangtuanya." Dengan pernikahan dibawah umur tentunya anak sudah tidak 
lagi bisa mengekspresi diri dan berpikir sesuai dengan usianya karena dituntut melaksanakan berbagai kewajiban sebagai seorang istri.

3. Hak dalam mengungkapkan sebuah pendapat serta didengarkan pendapatnya ; Mengenai hal ini (pernikahan dibawah umur) seorang anak berhak untuk ditanyakan apakah telah mengungkapkan pendapatnya dan didengar pendapatnya. Karena biasanya anak dinilai belum dapat untuk mengambil sebuah keputusan, sehingga orang yang lebih tua lah yang memutuskannya dengan dalih untuk kepentingan anak itu sendiri. Sedangkan banyak orang tua yang mengambil keputusan menikahkan anak dibawah umur untuk kepentingannya sendiri seperti karena motif ekonomi.

4. Hak untuk dapat istirahat dan mengolah waktu, bersosialiasi bersama teman seumuran, bermain dan berekspresi serta berkreasi sesuai dengan keinginannya. Dalam kasus pernikahan dini, anak tidak bisa lagi memiliki kesempatan untuk bermain dan bersosialisasi dengan teman seumurannya karena harus memikirkan rumah tangganya, anak yang melakukan pernikahan dini dituntut untuk dewasa dan bertanggung jawab kepada suami/istri dan anaknya.

5. Hak dalam memperoleh suatu perlindungan, dimana hak ini sesuai dengan Pasal 2 ayat (3)(4) UU tentang Kesejahteraan Anak, yang menyebutkan: “ bahwa anak memiliki hak untuk mendapatkan perlindungan dan pemeliharaan dari mulai dalam kandungan sampai dilahirkan. Anak memiliki hak mendapat 
perlindungan atas lingkungan hidup yang berbahaya serta hambatan mengenai pertumbuhan dan tumbuh kembangnya dengan wajar". ${ }^{14}$

Anak semestinya memiliki perlindungan atas suatu hal yang memiliki akibat negatif bagi tumbuh kembangnya, baik secara fisik ataupun psikisnya. Karena adanya pernikahan dini, maka orangtua dalam memberikan perlindungan kepada anaknya akan berkurang dikarenakan tanggung jawab akan dialihkan kepada suaminya. Dalam hal ini seharusnya anak perlu dihindarkan dari pernikahan dini karena akan berefek pada tumbuh kembangnya, secara fisik maupun psikisnya. Dalam UU No.23 Tahun 2002 mengenai Perlindungan anak termuat mengenai ancaman pidana bagi orang yang melanggarnya. Mengenai masalah tentang pernikahan dini, didalam UU pasal 82 mengenai Perlindungan Anak disebutkan bahwa "barang siapa melakukan bujuk rayu, tipu muslihat, serangkaian kebohongan, atau membujuk anak untuk melakukan atau membiarkan dilakukannya perbuatan cabul, maka dapat dijerat pidana penjara 315 tahun dan denda balik banyak Rp.300.000.000,00-dan paling sedikit Rp.60.000.000,00.”

Pada hakikatnya adanya perlindungan anak memiliki tujuan agar terlaksanakannya dua hal yakni hak-hak anak terpenuhi dan anak mendapatkan kesejahteraan. Para orang tua dan pihak yang bersangkutan harus mempertimbangkan dua tujuan diatas. Anak harus mendapatkan yang terbaik, jadi kepentingan anak harus diutamakan. Semua pihak yang bersangkutan mengenai dispensasi kawin diwajibkan untuk memperhatikan secara serius tentang hak anak tersebut beserta

14 Arif Gosita, Masalah Perlindungan Anak, (Jakarta: CV Akademika Pressindo, 
dengan kesejahteraan anak tersebut secara fisik ataupun psikisnya. Sesungguhnya yang dikatakan hak anak ialah berbagai kebutuhan yang menjadi dasar dimana anak seharusnya memperoleh jaminan atas keberlangsungan hidupnya, pertumbuhannya serta mendapat lindungan dari sesuatu hal bentuk perlakuan yang salah, seperti bentuk eksploitasi dan melantarkan anak, baik hal tersebut menyangkut hak ekonomi, hak sipil, serta hak mengenai sosial dan budaya.

Orang tua memiliki peran utama dalam terciptanya perlindungan anak serta kesejahteraan seorang anak. Walaupun di dalam undang-undang perkawinan menyebutkan mengenai batas umur seseorang dalam melakukan prkawinan yakni umur 19 tahun bagi laki-laki dan umur 16 tahun untuk perempuan, diharapkan orang tua mampu berfikir secara bijaksana dalam memberikan izin dan dalam mengambil sebuah keputusan mengenai pernikahan anak mereka. Dan orang tua diharapkan wajib untuk mence0gah perkawinan tersebut jika dinilai akan berdampak negatif pada kedua belah calon pengantin. Orang tua lah yang akan bertanggung jawab nantinya mengenai seluruh dampak negatif yang ditimbulkan atas pernikahan anak mereka. Orang tua memiliki Kewajiban tersebut telah diatur dalam Pasal 26 ayat (1) huruf (c) Undang-Undang Nomor 23 Tahun 2002 tentang Perlindungan Anak.

Jika memandang pada ketetapan Pasal 26 ayat 1 huruf c Undang-Undang Nomor 23 Tahun 2002 tentang Perlindungan Anak secara lugas telah memberikan larangan terhadap pernikahan dini yang mana pernikahan seseorang dibawah 18 tahun, demikian pula yang terdapat pada Pasal 7 ayat (1) UU Nomor 1 Tahun 1974. Tetapi, pada Pasal 7 ayat (2) UU Nomor 1 Tahun 1974 tentang Perkawinan terdapat 
penyimpangan, dimana diperbolehkannya pernikahan dini dengan syarat dispensasi kawin. Sekilas antara UU perkawinan dan Perlindungan Anak terjadi suatu kontradiksi didalamnya. Dengan adanya kontradiksi pasal pasal diantara kedua undang-undang tersebut maka perlu adanya ketelitian dalam mencari penyelesaian mengenai dispensasi kawin.

Dalam memutuskan perkara mengenai batas usia perkawinan anak maka UU Perlindungan Anak lah yang menjadi patokan, Walapun tidak dapat dipungkiri jika tetap adanya dispensasi kawin yang mana juga diatur oleh undang-undang. Harus diketahui jika dispensasi kawin adalah sebuah pengecualian atau aturan khusus sedangkan Undang-undang perlindungan anak yakni Pasal 26 ayat (1) huruf c adalah aturan yang sifatnya umum. Dalam perbedaan batas umur dewasa tersebut tidaklah hal yang keliru, asal didalam pelaksanaanya mengenai kepentingan yang dirasakan oleh warga Negara Indonesia melihat dari asas Lex specialist derogate legi generalis (hukum yang khusus menyampingkan hukum yang umum) serta bisa tercipta sesuai dengan tujuan. Dalam Undang-Undang No. 23 tahun 2002 Tentang Perlindungan Anak pernikaham dini sangat belawanan .

Pada UU tersebut dijelaskan bahwa yang dikatakan sebagai anak adalah seseorang yang usianya dibawah 18 tahun. Dari penjelasan diatas berarti seseorang yang usianya dibawah 18 tahun memiliki hak untuk hidup, tumbuh dan berkembang serta berpatisipasi dan mendapat perlindungan dari kekerasan maupun diskriminasi. Hak tersebut berhubungan mengenai hak dalam mendapatkan pendidikan yang sesuai. Dengan adanya hal ini seharusnya bisa menjadi petunjuk bagi pihak yang 
melakukan pernikahan terutama orang tua. Kedudukan dari orang tua sangatlah penting untuk tumbuh kembang anak yakni memiliki kedudukan dalam memberi sosialisasi mengenai nilai kebaikan dan norma yang berlangsung ataupun yang menjadi harapan masyarakat kepada anak-anak mereka yang diawali mulai dari perkara-perkara kecil yang terdapat di dalam keluarga berdasarkan tahapan perkembangan usia anak. ${ }^{15}$ Orang tua memiliki tugas dalam mendidik anaknya menjadi anak bangsa yang bisa bermanfaat untuk orang lain. Untuk itu orang tua perlu memperhatikan hal ini dan bisa memberikan motivasi kepada anaknya dalam mencapai impiannya.

Namun, ada aspek yang membuat hal tersebut menjadi terhambat, yakni alasan ekonomi serta adat budaya. ${ }^{16}$ pernikahan dini tidak hanya terdapat di kota besar namun terjadi di Kabupaten Tapin. Hal ini sesuai dengan daftar perkara yang termuat pada Pengadilan Agama Kabupaten Tapin(Rantau), kebanyakan dari mereka memiliki alasan karena sudah saling dekat dan takut terjadinya zina. Dalam hal ini diharapkan orang tua memiliki pertimbangan agar tidak menikahkan anak mereka. Sesuai pada UU No. 23 tahun 2002 bahwa : Orang tua memiliki kewajiban dan memiliki tanggung jawab dalam:

a. Mengasuh, menjaga, mengajar, dan memberikan perlindungan anak;

b. Mengembangkan bakat anak sesuai dengan minat dan keahliannya;

Bayyinatul Muchtaromah, Pendidikan Reproduksi Bagi Anak Menuju Aqil Khoiruddin Nasution, Hukum Perdata (Keluarga) Islam Indonesia dan Perbandingan Hukum Perkawinan di Dunia Muslim, hlm. 387. 
c. Mencegah terjadinya perkawinan pada usia anak-anak. (Pasal 26 UU No. 23 tahun 2002)

Hal ini dapat menjadi pedoman bagi orang tua agar selalu mengutamakan pendidikan anak supaya anak menjadi seorang yang mandiri sejalan dengan usianya. Pada dasarnya untuk mengurangi terjadinya pernikahan dini didalam adat maupun budaya, orang tua dapat mengubah pola pikirnya, dan dalam hal ini membutuhkan suport dari Semua kalangan termasuk suport dari pemerintah. Melihat dari pandangan kebanyakan wanita, usia diatas 20 tahun dinilai sudah tua, dan jika tidak cepat menikah akan mempermalukan keluarga, terlebih lagi ada pemikiran dimasyarakat lebih baik janda tapi masih muda daripada perawan tapi sudah tua. Sehingga menikahkan anak dibawah umur dianggap tepat oleh orang tua. Orang tua dalam menikahkan anaknya secara dini dinilai akan berdampak pada goyahnya keseimbangan sosial, yang mana didalamnya ditakutkan pihak yang berkaitan akan mengalami semacam kekerasan, dirampas haknya, diperdagangkan, serta mengalami kekejaman pedophilia.

Mengenai hak seorang anak, telah sangat dijelaskan didalam pasal 26 ayat 1 butir c UU No. 23 Tahun 2002 tentang Perlindungan Anak menyatakan bahwasanya Orang tua memiliki tanggung jawab serta berkewajiban untuk melakukan pencegahan terhadap adanya perkawinan di usia dini. Dari sudut pandang mengenai hak anak, dimuatnya kalimat tersebut adalah suatu kewajiban yang wajib dijadikan sebagai kepedulian bersama, karena jika melihat dari hak anak, anak-anak yang dinikahkan pada usia yang masih dalam masa kanak-kanak akan terampas haknya, seperti hak 
untuk mendapat pendidikan, bermain dengan kawan, serta hak untuk tumbuh dan berkembang dan alhasil anak akan dipaksa menjadi orang dewasa tidak pada waktunya.

Pada sisi lain, penyebab ekonomilah yang mempengaruhi terjadinya pernikahan dini. Tanpa memikirkan akibat yang akan terjadi nantinya, kebanyakan orang tua dari kalangan yang tidak mampu menikahkan anaknya dengan alasan akan mengurangi beban perekonomian keluarganya serta dapat membantu perekonomian keluarga. Dalam kasus ini akhirnya menimbulkan suatu perbuatan dengan menyalahgunaan "kekuasaan" atas ekonomi, dimana menilai seorang anak adalah sebuah aset bukan titipin dari Tuhan, dan yang paling jahat adalah menikahkan anak dibawah umur dengan dalih agama.

Dengan terdapatnya beberapa kejadian diatas, maka perlu adanya suatu hal yang dapat melindungi hak anak secara menyeluruh, diantaranya.

1. Memberi sebuah penjelasan terhadap masyarakat terutama keluarga mengenai hak anak yang mana tidak bisa dipisahkan karena telah terikat dengan anak tersebut;

2. Memberi pengetahuan mengenai kesehatan reproduksi dari mulai dini;

3. Menghimbau kepada masyarakat terutama keluarga untuk membentuk wilayah yang memiliki kesadaran terhadap anak;

4. Negara memberikan kebijakan untuk lebih memberikan perlindungan terhadap hak anak terutama mengenai aturan permasalahan pernikahan dini. 
Sesungguhnya, Substansi Hukum Islam ada untuk memberikan kemaslahatan sosial umat manusia dimasa sekarang maupun masa yang akan datang. Hukum Islam memiliki sifat yang humanis dan memberikan rahmat kepada alam semesta ini. Imam Al-Syatiby pernah mengatakannya didalam magnum opusnya dan kita harus memperhatikannya. Hal tersebut dimaksudkan agar Hukum Islam selalu berkembang sesuai waktu dan mengikuti pergantian zaman. ${ }^{17}$ Hal yang menjadi masalah adalah diantara kebijakan yang dikeluarkan pemerintah dengan hukum agama keduanya memiliki maslahat atau manfaat.

Larangan pernikahan dibawah umur yang diberlakukan oleh pemerintah memiliki alasan yang positif. Demikian pula dalam agama, memperbolehkan pernikahan dini juga memiliki sisi positif. Melihat dari permasalah tersebut, Dalam bukunya mengenai kemaslahatan, Izzudin Ibnu Abdusallam menjelaskan untuk melihat mana manfaat atau maslahat yang lebih utama untuk dilaksanakan. Seperti halnya dalam Kompilasi Hukum Islam (KHI) yang tidak jauh beda. Dimana pasal 15, KHI mengatakan bahwasanya batasan usia pernikahan persis seperti apa yang dijelaskan dalam pasal 7 Undang-Undang Perkawinan. Begitupun juga mengenai dispensasi perkawinan di bawah usia. Hal yang membedakannya, di dalam KHI terdapat keterangan mengenai kenapa dispensasi tersebut dapat diizinkan, yakni untuk kemaslahatan keluarga maupun rumah tangga. ${ }^{18}$

17 Imam Syatibi, al Muwafaqot, Beirut: Dar al Kutub Ilmiyah, hlm.220

18 Lihat pasal 15 Kompilasi Hukum Islam, 
Namun pada nyatanya, kebanyakan dalam pernikahan dini bukannya menimbulkan sebuah kemaslahatan namun berakhir pada sebuah perceraian. Di sisi lain, banyak akibat yang ditimbulkan dari pernikahan dini seperti kematian saat hamil atau melahirkan dikarenaan usia yang terbilang sangat muda. ${ }^{19}$ Berdasarkan hal tersebut, Undang-Undang memberikan aturan khusus yakni dispensasi kepada seseorang dibawah umur melakukan pernikahan. Sementara itu, orang tua pasti terlibat dalam pernikahan tersebut, dikarenakan ada aturan orang tualah yang menikahkan anaknya. Dalam pasal diatas tidak menjelaskan secara lugas mengenai larangan pernikahan dini, dengan terdapatnya dispensasi beserta izin dari pengadilan ataupun pejabat yang profesional .

Dalam hal ini, Undang-Undang Perkawinan dianggap telah keliru karena telah memberikan toleransi yang cukup besar mengenai pernikahan di bawah usia. beberapa yang dipermasalahkan pada Undang-Undang tersebut ialah Pasal 7 ayat (1), yang mengatur mengenai batasan usia pernikahan, yang mana digolongkan umur anak-anak. Pasal tersebut telah jelas berlawanan dengan Undang-undang Perlindungan Anak Pasal 1 ayat (2), dimana mendefinisikan seseorang dikatakan sebagai anak jika usianya belum sampai 18 tahun. "Anak adalah seseorang yang belum berusia 18 (delapan belas) tahun, termasuk anak yang masih dalam kandungan.” (Pasal 1 ayat (2) UU Perlindungan Anak). Terdapat 3 hal dimana harus mendapat perhatian mengenai pasal di atas. Pertama, persoalan mengenai batas usia perempuan yang dinilai terlalu sedikit jika dibandingkan dengan UU Perlindungan

19 http://www.depag.go.id/index.php?a=detilberita\&id=3955 
Anak. Yang kedua, terdapat batasan dimana seseorang bisa melakukan pernikahan jika sudah mencapai usia 16 untuk perempuan dan 19 untuk laki-laki, dengan demikian UU Perkawinan dinilai menerima adanya pernikahan dini.

Undang-Undang Perkawinan juga memberikan pengesahan melalui perizinan wali. Dimana UU perkawinan dinilai tidak lagi representatif terhadap perkembangan zaman. Perlu adanya perbaikan UU tersebut sesuai dengan kondisi yang ada sekarang. Dimana terdapat pemikiran lain yang mengatakan bahwa pernikahan dini lebih banyak negatifnya. Seperti yang tersirat di Undang-undang No. 23 tahun 2002, dengan adanya perlindungan anak diharapkan anak bisa mendapatkan haknya untuk berkembang, berkreatifitas, memiliki prestasi yang membanggakan, serta menjadi penerus bangsa yang baik untuk Indonesia serta anak dapat mendapatkan perlindungan dari berbagai kejahatan.

Adanya pernikahan dini ditakutkan akan menghambat hak anak untuk berkreatifitas dan menghambat impian anak di masa depan. Terlebih dengan terdapatnya dispensasi nikah yang akan menjadi kesempatan anak untuk menikah dini. Dimana dispensasi ini ada dengan maksud untuk menghindari perbuatanperbuatan diluar nikah seperti zina dan kehamilan diluar nikah yang menyimpang pada adat istiadat budaya maupun agama. Meskipun dalam pandangan agama menjadi suatu keharusan, namun tidak serta merta melupakan akibat yang akan terjadi nantinya. Dalam hal ini, wali juga ikut serta berperan untuk menikahkan anak sebagai salah satu syarat calon pengantin wanita dalam pernikahan dibawah umur. 
karena terdapatnya sistem perwalian maka pernikahan paksa bisa saja terjadi walapun melewati institusi dispensasi kawin.

Dalam kasus ini dinilai sangat berlawanan mengenai perlindungan hukum terhadap anak, yang mana menghambat berbagai hal seperti hak asasi seorang anak dan hak anak untuk bebas (fundamental rights and freedoms of children). Selain itu menurut UU mengenai Kesejahteraan Anak Pasal 9 menyatakan bahwasanya orang tua memiliki andil utama dalam mewujudkan kesejahteraan seorang anak, menjadikan anak yang baik secara rohani dan jasmani serta sosialnya. Permasalahan yang ditanyakan sekarang adalah, mengapa UU perkawinan mengatur tentang batas usia perkawinan seseorang? ada beberapa pendapat yang mengangap bahwa pembatasan usia perkawinan melalui peraturan yang dibuat oleh pemerintah dan DPRI ini, dilakukan untuk meminimalisirkan kelajuan penduduk.

Seperti yang kita ketahui, pemerintah sedang berusaha untuk mengontrol pertumbuhan penduduk dengan beberapa hal, salah satunya dengan Undang-Undang Perkawinan. Jika pernikahan dini tidak di batasi maka akan berakibat pada kematian ibu yang melahirkan dan juga angka kelahiran akan semakin banyak. Itulah alasan mengapa UU perkawinan ada, pertimbangan mengenai perkawinan bukan dari kedewasaan seseorang melainkan seseorang tersebut sudah matang secara biologis atau belum. Peraturan tersebut diharapkan mampu mencegah pernikahan dini yang banyak terjadi mulai dari tahun 1920-an. Peraturan ini dinilai telah sesuai dengan syarat pernikahan yakni kedua pasangan matang secara fisik maupun psikisnya. 
Tujuan yang diharapkan adalah terciptanya keluarga yang bahagia dan langeng sesuai dengan Ketuhanan Yang Maha Esa, serta memperoleh anak turun yang baik dan sehat. Seseorang dinilai telah siap secara mental dan mampu berfikir dewasa ketika berada di umur 16 tahun untuk perempuan dan laki-laki umur 19. Adanya batasan umur ini akhirnya mendapat perhatian ketika UU Perlindungan Anak disuarakan. Memang terdapat perbedaan jangka waktu yang cukup panjang antara penyusunan dan pembuatan UU perkawinan dan UU Perlindungan Anak. Dalam hal ini UU perkawinan dimaksudkan untuk meminimalisirkan jumlah penduduk sedangkan pada UU Perlindungan Anak bertujuan memberikan hak kepada anak untuk terus hidup dan berkembang serta berprestasi.

Seperti yang diketahui, adanya perlindungan anak dimaksudkan untuk memberikan hal yang terbaik untuk anak seperti memberikan hak-haknya serta menghargai pendapatnya. Masalah perlindungan anak mulai terdengar dan menjadi masalah serius ketika banyaknya kejadian kekerasan terhadap anak, banyaknya anak yang dipekerjakan secara tidak manusiawi, anak yang diperdagangkan, diskriminasi terhadap anak serta kejahatan lainnya.

Seharusnya seorang anak berhak mendapatkan kemerdekaan atas hidupnya. Agar seorang anak bisa mendapatkan masa depan yang diinginkannya. Seperti pada UU Perlindungan Anak poin (d) ” Bahwa agar setiap anak kelak mampu memikul tanggung jawab tersebut, maka ia perlu mendapat kesempatan yang seluas-luasnya untuk tumbuh dan berkembang secara optimal, baik fisik, mental maupun sosial, dan berakhlak mulia, perlu dilakukan upaya perlindungan serta untuk mewujudkan 
kesejahteraan anak dengan memberikan jaminan terhadap pemenuhan hak-haknya serta adanya perlakuan tanpa diskriminasi .”

Melihat dari penerapan kedua UU tersebut bisa kita amati pada asas hukum lex posterior derogate legi priori dan lex specialis derogate legi generali. Dimana dalam asas ini menjelaskan mengenai aturan mana yang harus dipilih untuk dijadikan sebagai peraturan. Yang berarti, permasalahan tidak berkaitan mengenai dirumuskannya suatu kebijakan hukum (formulation policy), melainkan mempunyai kaitan dengan game-rules dalam pelaksanaan hukum. Maka, dalam mengaplikasikan aturan para penegak hukum penting dalam mempelajari asas ini, untuk memilih aturan yang akan digunakan apakah yang "ini" atau yang "itu". Perlu adanya suatu harmonisasi diantara sistem hukum perkawinan yang berlangsung di Indonesia, agar legislasi yang muncul dari dampak perbedaan kepastian hukum mengenai permasalahan pernikahan dini bisa diatasi melalui cara transnasionalisasi hukum dengan memanfaatkan instrumen HAM yang mana dapat menjadi referensi permasalahan tersebut.

Mengenai selisih waktu diantara pembuatan UU Perkawinan dan UU Perlindungan Anak, dapat dijadikan sebagai pengamatan yang mana dapat disesuaikan dengan keadaan sekarang terlebih lagi mengenai pasal-pasal yang memiliki celah hukum jika terdapatnya pernikahan dibawah umur. Melihat dari faktor kesehatan, mengenai ketetapan pembatasan usia pernikahan dini, kita bisa mengacu pada dasar biologis tentang kesehatan reproduksi sesuai dengan UU No.36 tahun 2009 tentang Kesehatan, Pasal 136 ayat (2) "Upaya pemeliharaan kesehatan remaja 
sebagaimana dimaksud pada ayat (1) termasuk untuk reproduksi remaja dilakukan agar terbebas dari berbagai gangguan kesehatan yang dapat menghambat kemampuan menjalani kehidupan reproduksi secara sehat" .

Data yang tercatat pada Human Development Report pada tahun 2010, pada AKB di Indonesia sejumlah 31 per 1.000 anak yang dilahirkan. Dimana jumlah tersebut, 5,2 kali lebih besar jika disandingkan dengan Malaysia. Dan juga lebih besar dari Filipina yakni sebesar 1,2 kali serta 2,4 kali lebih besar dari Thailand. Hal yang menjadi penyebabnya adalah pernikahan di usia yang masih dini yaitu usia 16 tahun. Pada umumnya, dibeberapa negara telah mengumumkan bahwasanya umur yang diperbolehkan untuk menikah oleh negara adalah usia 18 tahun. Hal ini merupakan penerapan dari kebijakan Konvensi Hak-Hak Anak saat tahun 1989. Menurut UNICEF, Jika seseorang wanita hamil diusia yang masih di bawah 18 tahun maka secara fisik dia belum siap untuk melahirkan. Perempuan yang hamil sebelum usia 18 tahun secara fisik dan mental belum siap untuk melahirkan seorang anak. Rata-rata ibu yang berusia antara 15 sampai 19 tahun mengalami kematian saat melahirkan. Setiap anak memiliki hak assi menurut pandangan HAM.

Dalam konvensi PBB tentang Hak-Hak Anak (Convention on The Rights of The Child) tahun 1989 adalah instrumen hukum yang mengatur tentang hak seorang anak yang perlu mendapatkan perlindungan, yang mana sudah ditanda tangani atau disahkan oleh 191 lebih negara. Demikian pula, dengan Indonesia yang juga merupakan anggota PBB sudah mengesahkan melalui Kepres Nomor 36 tahun 1990. 
Maka, Konvensi PBB mengenai Hak Anak tersebut juga menjadi suatu hukum yang sifatnya mengikat bagi rakyat Indonesia.

\section{Kesimpulan}

Dispensasi nikah memberikan pembolehan bagi seseorang yang sebenarnya belum dapat melangsungkan pernikahan untuk dapat melaksanakan pernikahan yang sah dimata hukum negara. Dispensasi nikah jika dilaksanakan secara bijaksana dapat menjadi solusi dari sebuah permasalah yang sebenarnya pada awalnya adalah sebuah kesalahan moral yang dapat menghambat masa depan dan merendahkan derajat diri seseorang atas kesalahannya tersebut. Namun begitu sisi undang-undang yang lain memandang dispensasi nikah sebagai sebuah mekanisme yang justru mengganggu kehidupan masa remaja dan kanak-kanak dari yang bersangkutan.

Hal ini dapat menjadi benar dapat pula menjadi salah tergantung dari bagaimana keluarga besar dari kedua pihak manten muda memberikan dukungan baik moral maupun spiritual untuk terus menumbuhkembangkan anak walaupun disisi lain anak tersebut kini telah menikah dan secara perdata dianggap dewasa dan harus dapat mempertanggungjawabkan perbuatannya. Bagaimanapun juga dispensasi nikah bukan menjadi sebuah solusi yang mendidik bagi generasi muda usia remaja. Justru dikhawatirkan adanya dispensasi nikah semakin menyuburkan perilaku menyimpang pergaulan seks bebas dikalangan remaja di bawah umur.

\section{Saran}

1. Mengenai perkawinan di bawah umur, diharapkan antara UU perlindungan Anak dan UU Perkawinan dapat sejalan, dengan cara memperbaiki atau melakukan 
revisi terutama pada pasal 7 ayat (2) tentang dispensasi kawin yang dinilai memperbolehkan adanya pernikahan diusia dini. Dikarenakan jika dikaitkan dengan Pasal 26 ayat (1) huruf c diantara kedua ketetapan tersebut saling berlawanan.

2. Dilihat dari subtansi hukum, batas usia perkawinan seseorang bisa mengacu pada Konvensi Hak-Hak Anak. Dimana, umur seseorang dinyatakan sebagai anak jika belum genap 18 tahun. Untuk mencegah terjadinya pernikahan diusia belia, maka ada usulan mengenai Pendewasaan Usia Perkawinan. wali bukanlah seorang penentu melainkan hanya pemberi izin atau restu. Dimana hal tersebut dimaksudkan untuk menghindari nikah secara paksa.

\section{Daftar Pustaka}

Ahmad Rofiq, Hukum Islam di Indonesia, (Jakarta : PT Raja Grafindo Persada, 1995)

Arif Gosita, Masalah Perlindungan Anak, (Jakarta : CV Akademika Pressindo, 1987)

As'ad, Abdul Muhaimin. Risalah Nikah, (Surabaya: Bintang Terang, 1986).

Bayyinatul Muchtaromah, Pendidikan Reproduksi Bagi Anak Menuju Aqil Baligh, (Malang: UIN-Malang Press, 2008),

Gultom, Maidin. Perlindungan Terhadap Anak. (Bandung: PT. Refika Aditama, 2008).

Hadikusuma, Hilman. Hukum Perkawinan Indonesia Menurut Perundangan, Hukum Adat dan Hukum Agama. (Bandung: Mandar Maju, 1990). Harahap, Yahya. Hukum Perkawinan Nasional. (Medan: Zahir Trading, 1975). 
Katjasungkana, Soka Handinah. Perempuan dan Kekerasan. (Jakarta: Konsorsium

Swara Perempuan, 2005).

Khoiruddin Nasution, Hukum Perdata (Keluarga) Islam Indonesia dan Perbandingan Hukum Perkawinan di Dunia Muslim, Mufidah, Isu-Isu Gender Kontemporer Dalam Hukum Keluarga, (Malang: UIN-MALIKI PRESS, 2010)

Sudarsono, Hukum Perkawinan Nasional, cet. III. (Jakarta: Rineka Cipta, 2005).

Suma, Muhammad Amin. Hukum Keluarga Islam di Dunia Islam. (Jakarta: PT. Raja Grafindo Persada, 2005)

Supramono, Gatot. Segi-Segi Hukum Hubungan Luar Nikah. (Jakarta: Djambatan,1998).

Yunus, Muhamad. Hukum Perkawinan Dalam Islam. (Jakarta: Hidakarya Agung, 1979)

\section{Peraturan Perundang-undangan}

Undang-Undang Nomor 1 Tahun 1974 tentang Perkawinan;

Undang-Undang No 23 Tahun 2002 tentang Perlindungan Anak;

Kompilasi Hukum Islam 